assisted by an Agency health physicist, who will advise on all health physics matters relating to the project,

\section{Philippines}

A radiochemist will be sent to the Philippines to advise the Atomic Energy Commission on the organization of radioisotope courses and on the radiochemical facilities of the reactor to be built at the projected nuclear research centre near the University of the Philippines.

The International Atomic Energy Agency will also provide some equipment, including counters, ioniza tion chambers, rate-meters and other instruments.

\section{Turkey}

An expert in atomic energy planning will go to Turkey at the request of the Government to advise it on working out a detailed long-range atomic energy programme, on the establishment and operation of the necessary facilities and laboratories to implement this programme and on the setting up of new training and research centres.

A research and training reactor is under construction near Istanbul. To elaborate a detailed and effective research and utilization programme for the reactor the Turkish Atomic Energy Committee has established a committee of scientists and requested the International Atomic Energy Agency to provide the services of an expert on reactor utilization to assist in the activities of the Committee. In addition, the expert will advise on setting up and utilizing a sub-critical assembly in the Faculty of Science at the University of Ankara.

\section{Venezuela}

A legal expert will be sent to Venezuela to advise the Government on legislative and administrative problems relating to its atomic energy programmes. and assist in planning and drafting the required legislation as well as in training Venezuelan staff on legal matters.

\section{Yugoslavia}

An expert in the agricultural applications of isotopes will work at the Yugoslav Institute for the Application of Nuclear Energy in Agriculture, Veterinary Sciences and Forestry in Belgrade. He will assist in equipping the Institute and in the organization and development of a laboratory. To assist the expert in his work and to help in setting up the laboratory the Agency will provide counting and dosimetry equipment.

An expert in the medical uses of atomic energy will be sent to Yugoslavia to initiate elinical research work at the medical radioisotope laboratories in Belgrade, Ljubljana and Zagreb. He will also lecture on the applications of isotopes at a course organized by the Federal Nuclear Energy Commission and advise the Commission on future activities related to the medical applications of radioisotopes.

One biochemist will be attached to the Institute for Biology at Zagreb to help its staff to fight fasciolosis, a cattle disease which is estimated by the Government to cost Yugoslavia 8,000 million dinars annually. He will assist in equipping the radioisotope laboratory of the Institute and train the local staff in the applications of tracers to research. Some nuclear laboratory equipment will also be provided.

\title{
THE RESEARCH ASSOCIATION OF BRITISH FLOUR MILLERS
}

\section{NEW LABORATORIES}

\begin{abstract}
CONSIDERABLE extensions to the laboratories $\lambda$ of the Ceroals Research Station, provided by the Millers Mutual Association, and which include new analytical and research laboratories, animal unit, workshop, committee, lecture and common rooms and canteen, were opened by Lord Rank on May 4. In his speech, he said that there was no need now to remind any industrialist that to be successful he must have the best scientific advice and stimulus at his elbow. While individual milling companies had their own scientific units, the industry looked to the Research Association for leads on major scientific developments; the Research Association was, in fact, the scientific headquarters of the milling industry. After stressing the importance of nutritional research, he went on to say that in Great Britain we had the best and probably the cheapest bread in the world, and in this achievement the Research Association had played a big part. He could say this with authority, because he was president of the Association during 1930-52.
\end{abstract}

At the luncheon that followed, the president, $\mathrm{Mr}$. L. Hector Read, proposed the health of the guests. Before doing so, he thanked Lord Rank and his colleagues for providing the additions to the laboratories and he also expressed the indebtedness of the Research Association for the great help and encouragement received from the Department of Scientific and Industrial Research during the thirty-seven years since the Association was founded. In welcoming the principal guest, Lord Cohen of Birkenhead. he spoke of him as a leader in his profession, as one who has always been keenly interested in scientific and medical research, and as the outstanding modical statesman of the a.ge. In replying, Lord Cohen pointed out that biology, of which medicine is simply an aspect, had advanced mainly by the application of physics and chemistry to the elucidation of complex biological phenomena. For this reason it was to him of immense significance to see such application being made by the Research Association to the problems of cereals. $\mathrm{He}$ noted, too, investigations involving engineering, bacteriology, mycology, entomology, zoology and geneties. With regard to the latter, "Bread and Breed" was indeed a most appropriate title. The restheties of bread, its palatability and appearance, and other fields of the arts also entered into the work of the Association, and he wondered whether here in these laboratories would be found the appropriate marriage of the two cultures, science and art, of which Sir Charles Snow spoke recently.

The laboratorios were afterwards opened for inspection, and a number of demonstrations were given illustrating the current research programme. These included the structure and chemistry of the 
No. 4728 June 11,1960

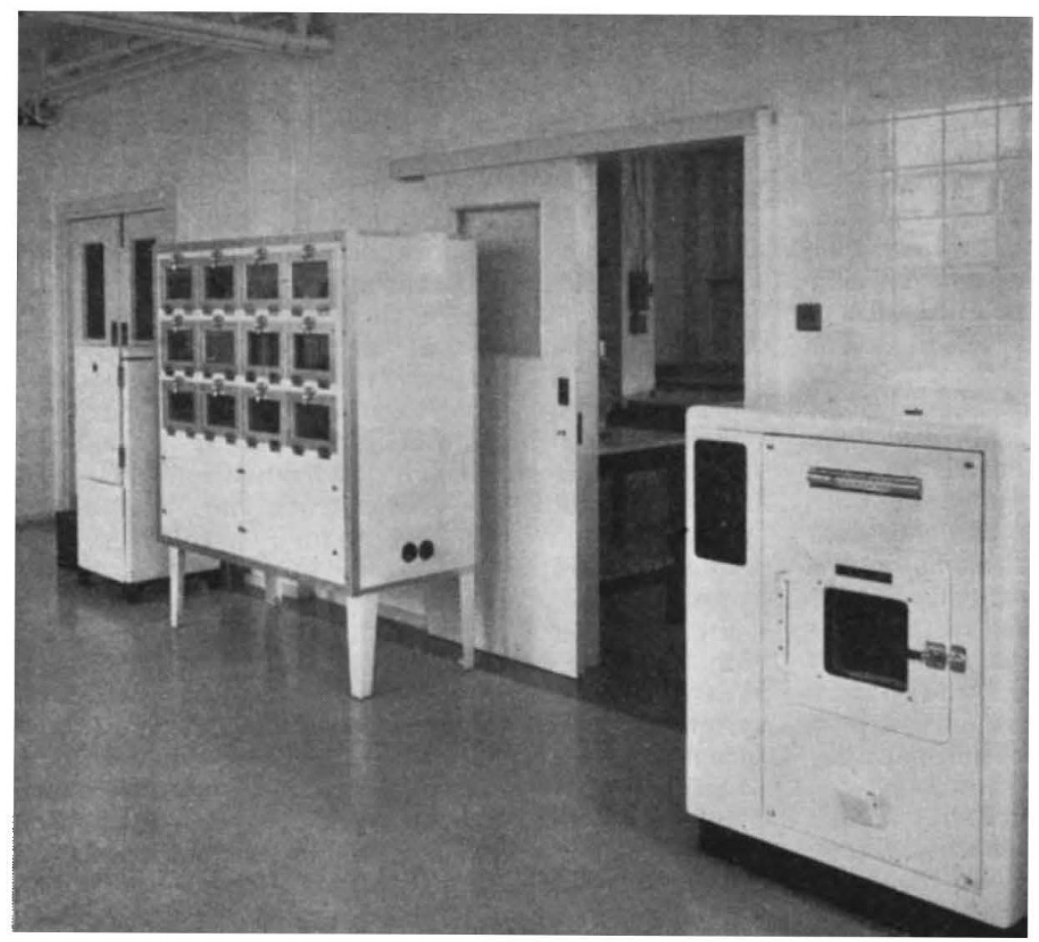

Fig. 1. Corner of Bread Bakery, Cereals Research Station, St. Albans, leading to the Constant Temperature Laboratory

wheat grain, with the distribution of the $\mathrm{B}$ vitamins and vitamin $\mathrm{E}$, varietal differences in wheat and how they affect milling and baking properties, the chemistry of the wheat proteins, nutritional studies on wheat and flour as shown by experiments on the rat, experiments on dental caries, the chemistry to refer to our reeent. work on the separation from ordinary flour, by air classifieation, of fractions rich or poor in protein. This may be a major development in the history of flour milling. I believe therefore that the Research Association has for some years struck about the right balance between basal and applied research". of cereal lipids, certain aspects of flour milling technology, including the air classification of flour, rheological studies on dough, problems specific to oats and oat products and the avoidance of rodent contamination of cereals on the farm.

To mark the oecasion, a book was prepared, entitled "The Research Association of British Flour Millers, 1923-1960", which includes abstracts of the 376 scientific and technical papers published by the Association. The abstracts are grouped in three categories-basic, agricultural and technological. In the introduction, the president writes: "Speaking for my Council, I would like to stress that in our opinion the main function of the Research Association is to carry out basal research. I would add. too, that in our experience the practical results that have followed amply justify this policy. That does not mean that some routine and $a d$ hoc work is not.necessary. It is, if only to keep the staff in touch and in sympathy with millers' day to day problems. Nor has research on flour milling as such been neglected. I have only

\section{NATURE AND EXPLOITATION OF CROP PLANT RESISTANCE TO DISEASE}

\begin{abstract}
A SYMPOSIUM on the nature and exploitation of crop plant resistance to disease, organized jointly by the Association of Applied Biologists (president, Dr. R. V. Harris) and the British Mycological Society (president, Mr. E. C. Large), was held at the London School of Hygiene and Tropical Medicine during January 8-9.

The first day's proceedings were devoted to studies on the host plant, and, in a general introduction, Dr. G. D. H. Bell said how much he appreciated the initiative of the sponsors in arranging this important symposium. The efficient exploitation of disease resistance required the collaboration of both the pathologist and the plant breeder. Obviously the breeder tended to be more concerned with the host than with the pathogen, and although it was accepted as sound breeding policy to handle disease resistance in much the same way as other breeding characters, the genetics of the pathogen had to be considered as well as that of the host. Disease resistance was, of course, expressed in different ways, while various systems of genetic control were known. Major gene resistance in the host had been exploited
\end{abstract}

extensively, but that based on minor genes was undoubtedly safer in many circumstances.

Dr. R. C. F. Macer (Plant Breeding Institute, Cambridge), who considered developments in breeding disease-resistant cereals, suggested that the problems were for the first time being dealt with adequately in Great Britain. The synthesis of wheat lines with genes for resistance to Puccinia glumarum, Erysiphe graminis and Cercosporella herpotrichoides were given as examples of progress being made; in some cases it had been found desirable to use sources of resistance found in allied species and genera. The closed-flowering character of barley was described as an escape mechanism giving protection from all races of Ustilago nuda.

Some of the difficulties in breeding for resistance to certain diseases in vegetable crops were outlined by Dr. J. C. Haigh (Wellesbourne), who described the present position in lettuce with regard to mosaic disease, downy mildew (Bremia lactucae) and mould (Botrytis cinerea). He also referred to the difficulties of using Lycopersicum pimpinellifolium and $L$. hirsutum as sources of resistance to Cladosporium 